Supplement of

\title{
Isoprene and monoterpene emissions in south-east Australia: comparison of a multi-layer canopy model with MEGAN and with atmospheric observations
}

Kathryn M. Emmerson et al.

Correspondence to: Kathryn M. Emmerson (kathryn.emmerson@csiro.au)

The copyright of individual parts of the supplement might differ from the CC BY 4.0 License. 


\section{The Australian Biogenic Canopy and Grass Emissions Model (ABCGEM)}

The ABCGEM model was developed 15 years ago at CSIRO to provide a spatially and temporally resolved interactive biogenic emission inventory for the C-CTM. ABCGEM treats the emissions of reactive organic carbon from a full tree canopy (for which in-canopy gradients of temperature and radiation are parameterised) and from pasture and grasses. Cases which fall between these extremes (i.e. sparse canopy with an under-layer of pasture) are treated as a linear combination of the two separate approaches.

The emission rate, ER ( $\left.\mu \mathrm{g}-\mathrm{C} \mathrm{m}^{-2} \mathrm{~h}^{-1}\right)$ within the model from either tree canopy or grasses is a function of the fraction of the model grid cell occupied by tree canopy or grass, $\mathrm{F}$, the total leaf biomass $\mathrm{B}_{\mathrm{m}}\left(\mathrm{g} \mathrm{m}^{-2}\right)$, and plant genus-specific emission rate $10 \mathrm{Q}\left(\mu \mathrm{g}-\mathrm{Cg}^{-2} \mathrm{~h}^{-1}\right)$.

$E R=F \times B_{m} \times Q$

$\mathrm{B}_{\mathrm{m}}$ is the total dry weight of leaves extending from the ground to the canopy/grass height, $\mathrm{h}_{\mathrm{c}}$ per unit area of ground. Both $\mathrm{B}_{\mathrm{m}}$ and F relate to the projected leaf area index, LAI $\left(\mathrm{m}^{2} \mathrm{~m}^{-2}\right)$. Thus:

$F=1-\exp ^{(-0.5 \times L A I)}$

$15 B_{m}=L A I \times L M A$

Where LMA is the leaf mass per unit area $\left(\mathrm{g} \mathrm{m}^{-2}\right)$. $\mathrm{B}_{\mathrm{m}}$ changes with the seasonal variation in LAI and the relationship in equation 3. LMA is $100 \mathrm{~g} \mathrm{~m}^{-2}$ for trees, consis tent with studies in National Parks within the Sydney GMR (Wright et al., 2002), and $250 \mathrm{~g} \mathrm{~m}^{-2}$ for grass. This higher ratio for grass is based on localmeasurements of pasture grass by Kirstine et al. (1998), but is more than expected by the global database of plant traits (Kattge et al., 2011). It does allow for very low values of LAI $\mathrm{I}_{\mathrm{G}}$

20 in ABCGEM, but until mapped $\mathrm{B}_{\mathrm{m}}$ becomes available, equation 3 is a source of uncertainty. The leaf level emis sions, $\mathrm{Q}$, are calculated for isoprene and monoterpenes in the tree canopy model (section 1.1), and for the grass model(section 1.3).

\subsection{The tree canopy model}

The tree canopy is divided into 10 vertical layers each of which has a specified height and LAI. The vertical dis tribution of LAI follows a triangulardis tribution (Lamb et al., 1993), with the peak LAI occurring at two-thirds of the canopy height and drops to zero at one-third of canopy height (i.e. the trunk). The canopy model takes input conditions of solar radiation and air temperature and computes in-canopy gradients of temperature and solar radiation, for sunlit and shaded leaves. Layer-specific biogenic fluxes are then generated using the Guenther algorithms and a species-specific emission factor, normalised to $30^{\circ} \mathrm{C}$ and $1000 \mu \mathrm{mol} \mathrm{m} \mathrm{m}^{-2} \mathrm{~s}^{-1}$.

\subsubsection{Temperature Function}

30 The temperature within the 10-layer canopy is assumed to change in proportion to the cumulative leaf area index, LAI , summed from the top down. During daylight hours, the leaf level temperature, $\mathrm{T}_{\text {leaf }}$ of the $\mathrm{i}^{\text {th }}$ layer, is approximated by the LAIweighted interpolation of the leaf temperature between the top of the canopy, $\mathrm{T}_{\mathrm{h}}$ and the temperature at the canopy base, $\mathrm{T}_{\text {bare }}$.

$$
T_{\text {leaf }}^{i}=T_{h}+\left(L A I_{C} / L A I\right)\left[T_{\text {base }}-T_{h}\right]
$$

where LAI is the projected canopy leaf area index per unit area of ground extending from the ground to $\mathrm{h}_{\mathrm{C}}$, the canopy height. ABCGEM does not consider the energy balance within the canopy, instead as suming that $T_{\text {base }}$ does not vary significantly 
diurnally, for a densely shaded canopy with no horizontal temperature advection. The 24-hour average temperature is used for $\mathrm{T}_{\text {base. At night, a height-based linear interpolation replaces equation } 4 .}$

The temperature correction function for is oprene emissions, $C_{T}$ for each layer is given by equation 5 (Guenther et al., 1991):

$\mathrm{C}_{\mathrm{T}}=\frac{\exp \frac{\mathrm{C}_{\mathrm{T} 1}\left(\mathrm{~T}_{\text {leaf }}-\mathrm{T}_{\mathrm{S}}\right)}{\mathrm{RT}_{\mathrm{S}} \mathrm{T}_{\text {leaf }}}}{1+\exp \frac{\mathrm{C}_{\mathrm{T} 2}\left(\mathrm{~T}_{\text {leaf }}-\mathrm{T}_{\mathrm{M}}\right)}{\mathrm{R}_{\mathrm{S}} \mathrm{T}_{\text {leaf }}}}$

5 where $\mathrm{R}=8.314 \mathrm{~J} \mathrm{~K}-1 \mathrm{~mol}^{-1}, \mathrm{C}_{\mathrm{T} 1}=95,000 \mathrm{~J} \mathrm{~mol}^{-1}, \mathrm{C}_{\mathrm{T} 2}=230,000 \mathrm{~J} \mathrm{~mol}^{-1}, \mathrm{~T}_{\mathrm{M}}=314{ }^{\circ} \mathrm{K}$ and $\mathrm{T}_{\mathrm{S}}=303{ }^{\circ} \mathrm{K}$ is the standard temperature. Whilst the above parameters have changed little since Guenther et al. (1991), there is evidencethat temperature and light responses differ among plant species and can even vary among shade- and sun- adapted leaves within canopy and individual trees (Sharkey et al., 1996; Harley et al., 1997).

\subsubsection{Radiation Function}

10 Leaf-level emis sions require the specification of the incident photosynthetically active radiation (PAR) through the canopy. The attenuation of radiation through the canopy is determined using a relationship developed by Zhang et al., (2001).

$$
P A R_{\text {shade }}=R_{\text {diff }} e^{\left(-0.65 L A I_{i}^{1.5}\right)}+0.07 R_{\text {dir }}\left(1.1-0.1 L A I_{C}\right) e^{-\cos \theta}
$$

where PAR $_{\text {shade }}$ is the PAR flux on the shaded leaves, $R_{\text {diff }}$ is the diffuse radiation at the top of the canopy, $R_{\text {dir }}$ is the direct radiation at the top of the canopy, and $\theta$ is the solar zenith angle. The PAR fluxincident on the sunlit leaves is given by Norman 15 (1982):

$\mathrm{PAR}_{\text {sun }}=\mathrm{R}_{\text {dir }} \cos \delta / \cos \theta+\mathrm{PAR}_{\text {shade }}$

where $\delta$ is the mean angle between the direction of leaves and the sun's rays.

In the case of isoprene emissions, the radiation correction function $C_{\mathrm{L}}$ is given by equation 8 (Guenther et al., 1993):

$C_{L}=\frac{\alpha C_{L 1} L}{\sqrt{1+\alpha^{2} L^{2}}}$

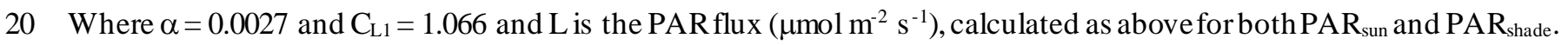
A simple canopy radiation attenuation model is used to calculate the fraction of leaf area that is sunlit and shaded. Following Norman (1982), the cumulative leaf area index (integrated fromthe top of the canopy downwards) of sun lit leaves, LAI $_{\text {sun }}$ and shaded leaves, $\mathrm{LAI}_{\text {shade }}$, is given by equations 9 and 10 .

$\mathrm{LAI}_{\text {sun }}=2 \cos \theta\left[1-e^{\left(-0.5 \mathrm{LAI}_{\mathrm{C}} / \cos \theta\right)}\right]$

25 and $\mathrm{LAI}_{\text {shade }}=\mathrm{LAI}_{\mathrm{C}}-\mathrm{LAI}_{\text {sun }}$

\subsubsection{Layer-specific emission algorithm for isoprene}

Following the prescription of the layer-specific leaf temperature, solar radiation flux and LAI, a leaf-level emis sion rate $\mathrm{Q}_{\text {leaf }}$ for the $\mathrm{i}^{\text {th }}$ layer, is calculated using equation 11 . Note equation 11 only applies to is oprene:

$$
Q_{\text {leaf }}^{i}=C_{T}^{i}\left[C_{L s u n}^{i} L A I_{\text {sun }}^{i}+C_{\text {Lshade }}^{i} L A I_{\text {shade }}^{i}\right]
$$

$30 \mathrm{Q}_{\text {leaf }}^{\mathrm{i}}$ is dimensionless. The emis sion rate is an LAI-weighted sumof the flux from the sunlit and shaded areas of the leaf. 


\subsubsection{Layer-specific emission algorithm for monoterpenes}

Monoterpene emissions are regarded as temperature dependent in ABCGEM. This dependence is related to the vapour pressure and transport resistance along the diffu sion path, as sociated with volatilization of the monoterpenes out of leaf storage organs (Tingey et al., 1980; Simon et al., 1994). The emission response to temperature in the $i^{\text {th }}$ layer has an exponential increase with 5 temperature, described using the formula by Tingey et al. (1980):

$\mathrm{Q}_{\text {leaf }}^{i}=\exp \left(\beta\left(\mathrm{T}_{\text {leaf }}-\mathrm{T}_{\mathrm{S}}\right)\right) \times L A I_{i}$

Where $\mathrm{Q}_{\text {leaf }}$ is $_{\text {in }}$ the monoterpene emission rate at the leaf temperature $\mathrm{T}_{\text {leaf }}$ within each layer, $\mathrm{i}, \mathrm{T}_{\mathrm{s}}$ is the standard temperature (303 $\mathrm{K}$ ) and $\beta\left(\mathrm{K}^{-1}\right)$ is an empirical coefficient set to $0.09 \mathrm{~K}^{-1}$ for all monoterpenes and plant species (Guenther et al., 1993). $\mathrm{LAI}_{\mathrm{i}}$ is the leaf area index (sunlit and shaded) within layer $\mathrm{i}$.

\section{1.1.5 Tree canopy total emission rate}

The tree canopy total emis sion rate, $\mathrm{Q}\left(\mu \mathrm{g}-\mathrm{C} \mathrm{g}^{-1} \mathrm{~h}^{-1}\right)$, is obtained by scaling the leaf-level emission rate for either isoprene or monoterpenes, by the projected LAI. For our 10-layer canopy,

$Q=E F_{S} \sum_{i=1}^{10-\text { layer }}\left[Q_{\text {leaf }}^{i}\right] / L A I$

Where $\mathrm{EF}_{\mathrm{S}}$ is the species-specific normalised emission factor $\left(\mu \mathrm{g}-\mathrm{Cg}^{-1} \mathrm{~h}^{-1}\right) . \mathrm{EF}_{\mathrm{S}}$ is modified according to the ambient conditions of temperature and PAR (is oprene only) on leaves within each layer. 


\section{CSIRO CTM model setup}

\subsection{The LAI input datasets}

The LAI parameter influences is oprene and monoterpene emissions, impacting on the temperature and PAR throughout the canopy (equations 4 to 13), the biomass density (equation 3) and, for ABCGEM, the fractional coverage (equation 2). Figure

51 shows the ABCGEM LAI tree and grass products. Whilst the spatial dis tribution in LAI protrudes into the sea due to the coarse resolution of the parent dataset, the as sociated land use for these locations (ocean) used in the modelensure there are no biogenic emis sions. Tree canopies have much higher LAIs than grass. However the grass LAI varies with season, whilst the tree LAIdoes not (evergreen species). The grass LAI dataset varies monthly, peaking at $3.6 \mathrm{~m}^{2} \mathrm{~m}^{-2}$ within the inner domain during winter. In summer/early autumn when our field campaigns took place, the peak grass LAIranges from $0.7-2.1 \mathrm{~m}^{2} \mathrm{~m}$

$10 \quad 2$. This range yields $B_{m}$ between $175-525 \mathrm{~g} \mathrm{~m}^{-2}$, and a fractional area for grass between $0.30-0.65$. However due to negligible grass emission factors, these additional grass LAI values are considered 'empty' and do not contribute to the modelled emissions of is oprene or monoterpenes.
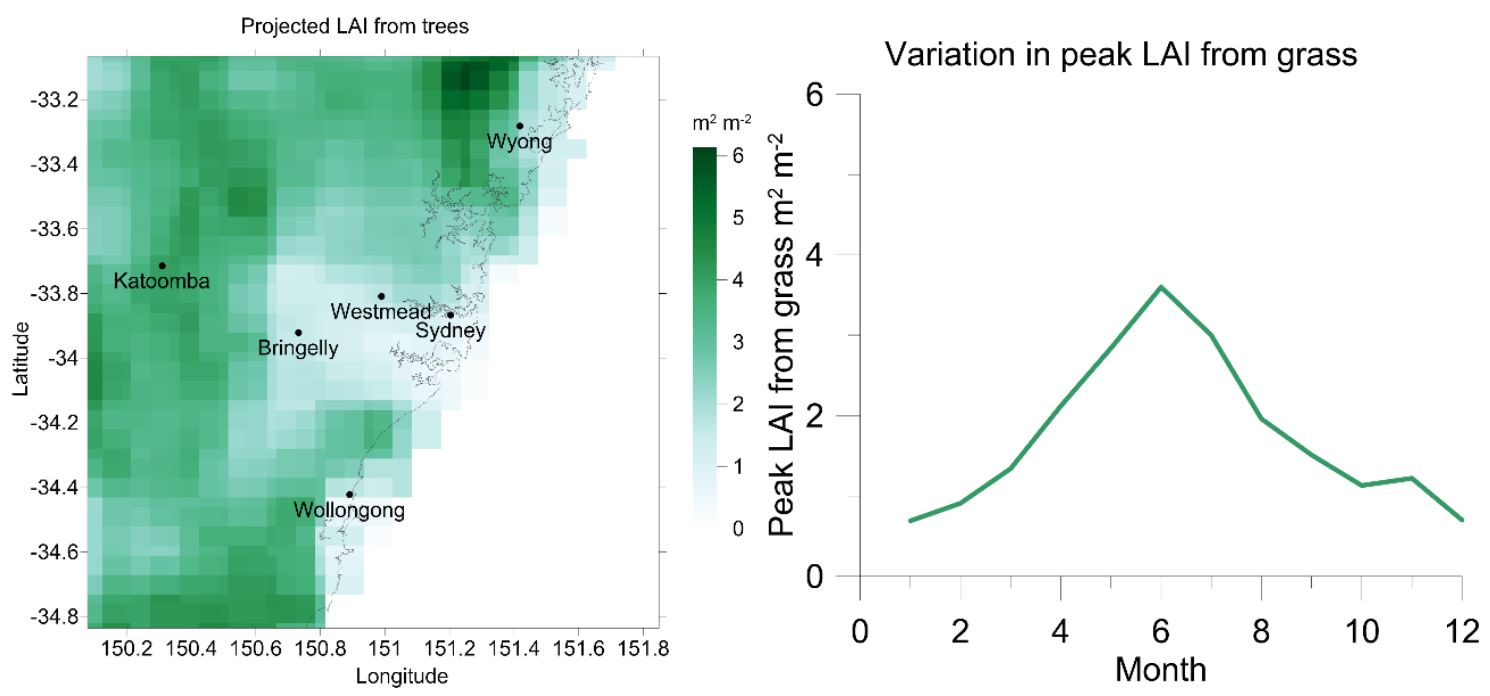

15 Figure 1 Projectedleaf area index for (left) trees and (right) grass within the inner domain for ABCGEM.

\subsection{MEGAN emission calculation}

The equations for the MEGAN emissions are repeated here fromEmmers on et al. (2016). They relate to the implementation of MEGANv2.1 within the C-CTM.

20

MEGANv2.1 provides two approaches for estimating emission factors. The first is to use the 16 plant functional type (PFT) distributions and the global average PFT specific emis sion factors listed in Table 2 of Guentheret al. (2012). In this case the emission rate, $\mathrm{R}\left(\mu \mathrm{g} \mathrm{m}^{-2} \mathrm{hr}^{-1}\right)$ of species $\mathrm{i}$ in any grid box, will be sensitive to the PFT distributions used for the MEGAN simulation (equation 15):

$$
R_{i}=\sum_{j=1}^{n P F T}\left(E F_{i j} \times \gamma_{i j} \times \chi_{j}\right)
$$

where $\mathrm{EF}_{\mathrm{ij}}$ is the emission factor $\left(\mu \mathrm{g} \mathrm{m}^{-2} \mathrm{hr}^{-1}\right)$ of species $\mathrm{i}$ under standard conditions for PFT $\mathrm{j}$ with fractional grid box areal coverage $\chi_{\mathrm{j}}$. The emission activity factor $\gamma_{\mathrm{ij}}$ (dimensionless) accounts for emis sion control processes and uses the following variables to drive the canopy model: compound class, res ponse to light and temperature, leaf age, soil moisture, $\mathrm{CO}_{2}$ and LAI. The second approach is to use MEGAN global emission factor maps, which are based on plant type composition and plant type specific emiss ion factors. In this case, the MEGAN simulation uses PFTs to define the canopy environment characteristics 
and to define the fractional grid box areal coverage, but the res ults are not as sensitive to the PFT dataused. The emis sion rate, $\mathrm{R}$ for species i in a given grid cell, $\mathrm{xy}$ is (equation 16 ):

$$
R_{i}=E F_{i, x y} \sum_{j=1}^{n P T}\left(\gamma_{i j} \times \chi_{j}\right)
$$

This study uses both approaches, the latter approach for 10 species where emis sion factor maps are available, and the former

5 approach for allotherspecies.

\subsection{Differences in the temperature and radiation activity functions}

There are differences in the algorithms for the temperature and radiation activity functions between ABCGEM and MEGAN, which will impact on the processing of the emis sion factors. The temperature activity function is shown in Figure 2 (top), for isoprene and monoterpenes. The temperature activity function for isoprene in both emission models is similar until $303 \mathrm{~K}$

10 when MEGAN begins to plateau and ABCGEM keeps increasing. For monoterpenes, the ABCGEM temperature activity function is always higher than MEGAN for any monoterpene species. We plot both the light dependent and independent temperature functions for $\alpha$-pinene, and then the range in light independent monoterpenes. At $293 \mathrm{~K}$, the ABCGEM function is $180 \%$ higher than the MEGAN $\alpha$-pinene function and $40 \%$ higher than MEGAN monoterpenes with a light independent function of 0.8 .

15 Figure 2 (bottom) also shows that the radiation activity function (RAF) in ABCGEM is capped at 1.066, the value of $\mathrm{C}_{\mathrm{L} 1}$ in equation 8 of the supplementary material. ABCGEM reaches a RAF of 1 at the standard photosynthetic active radiation (PAR) of $1000 \mu \mathrm{mol} \mathrm{m} \mathrm{m}^{-2} \mathrm{~s}^{-1}$, whilst MEGAN achieves a RAF of 1 by $600 \mu \mathrm{mol} \mathrm{m} \mathrm{m}^{-2} \mathrm{~s}^{-1}$. ABCGEM will produce more isoprene than MEGAN at very low light levels $<500 \mu \mathrm{mol} \mathrm{m} \mathrm{m}^{-2} \mathrm{~s}^{-1}$, but at the standard PAR, MEGAN produces $41 \%$ more is oprene than ABCGEM. Observed noontime PAR at the MUMBA and SPS2 campaigns were $\sim 1600 \mu \mathrm{mol} \mathrm{m}^{-2} \mathrm{~s}^{-1}$ and $\sim 1200 \mu \mathrm{mol} \mathrm{m}^{-2} \mathrm{~s}^{-1}$ 20 respectively (Emmerson et al., 2016). 

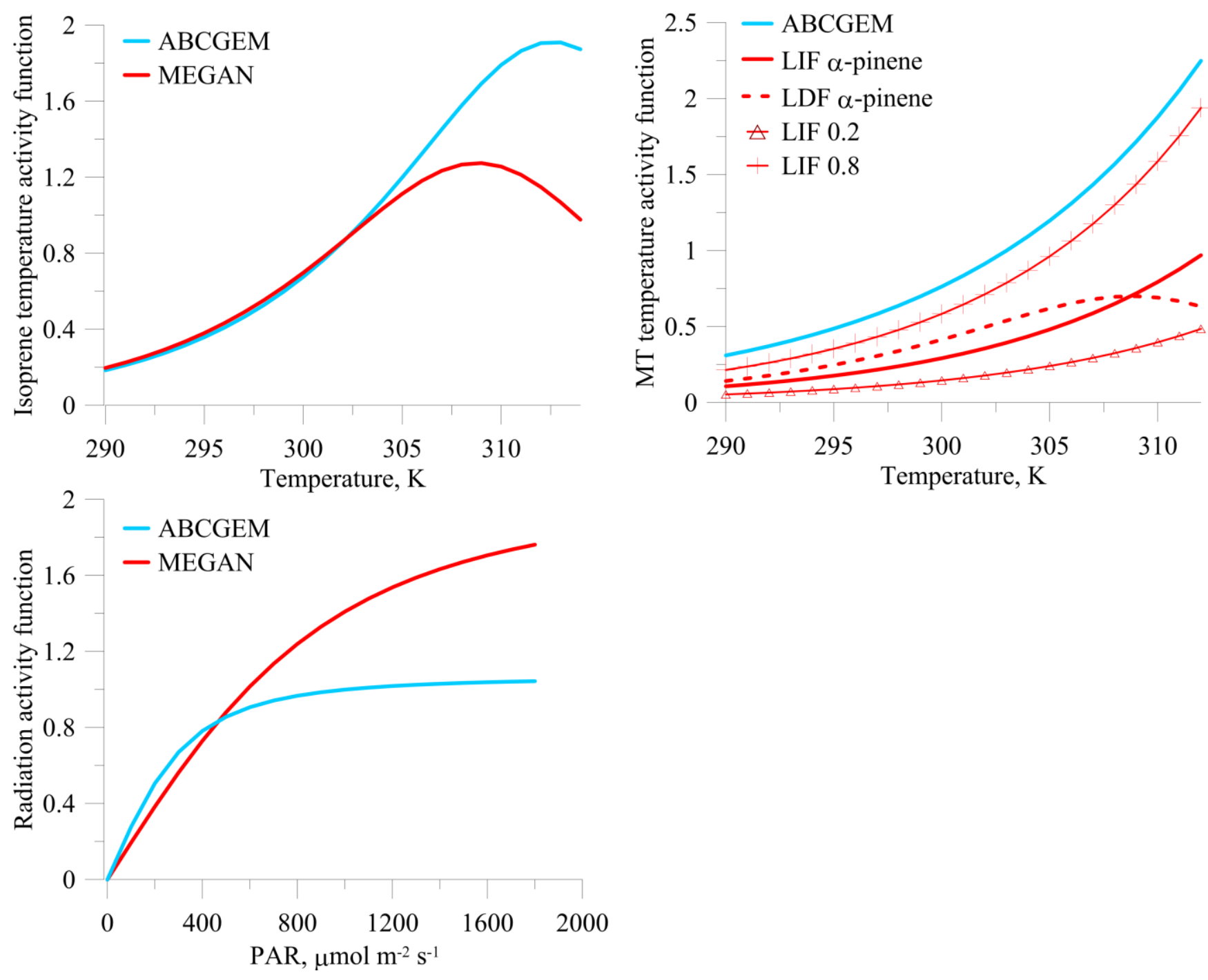

Figure 2 (top) Temperature activity functions in ABCGEM (blue) and MEGAN (red) for isoprene (left) and monoterpenes (MT, right). LIF is light independent fraction, LDF is light dependent fraction. (bottom) Radiation activity function, demonstrated for non-shaded leaves. 


\section{ABCGEM emission estimate uncertainty analysis}

The uncertainty analysis of these BVOC emission estimates proceeds via the ABCGEM emission algorithm, using the principles in the Guide to Expression of Uncertainty in Measurement and the law of propagation of uncertainty (JCGM, 2008)

5 also known as the error propagation equation (Berrington and Robinson, 1992; Harris, 2003). All uncertainties in this analysis are expanded uncertainties with a coverage factor $\mathrm{k}=2$. The as sociated level of confidence of the uncertainty interval is typically $95 \%$.

The equation for propagation of uncertainty for the function $x=f(u, v, \ldots)$ is:

$10 \sigma_{x}^{2}=\sigma_{u}^{2}\left(\frac{\partial x}{\partial u}\right)^{2}+\sigma_{v}^{2}\left(\frac{\partial x}{\partial v}\right)^{2}+2 \sigma_{u v}^{2}\left(\frac{\partial x}{\partial u}\right)^{2}\left(\frac{\partial x}{\partial v}\right)^{2} \ldots$

In this equation and subsequent uncertainty interpretations, variances are represented as population v alues. In the calculations the experimentally determined variances are used. We assume that all uncertainties evaluated here are uncorrelated, except where explicitly stated.

\subsection{ABCGEM emission uncertainty}

15 The basic equation for BVOC emis sion estimates includes the following terms:

$\mathrm{B}_{\mathrm{m}} \quad$ totaldry mass of leaves extending from the ground to the canopy/grass height per unit area of ground, $\left(\mathrm{g} \mathrm{m}^{-2}\right)$

$\mathrm{h}_{\mathrm{C}} \quad$ canopy/grass height (m)

F fraction of the model grid cell occupied by treecanopy or grass (dimensionless)

LAI leaf area index, $\left(\mathrm{m}^{2} \mathrm{~m}^{-2}\right)$

20 LMA leaf mass per unit leaf area, $\left(\mathrm{g} \mathrm{m}^{-2}\right)$

PAR photosynthetic active radiation

$\mathrm{T} \quad$ temperature $(\mathrm{K})$

ER emission rate, $\left(\mu \mathrm{g}-\mathrm{Cm}^{-2} \mathrm{~h}^{-1}\right)$

Q plant genus-specific emission rate $\left(\mu \mathrm{g}-\mathrm{Cg}^{-2} \mathrm{~h}^{-1}\right)$

25 EF plantgenus-specific emissionfactor

SZA solar zenith angle

With subscripts

$\mathrm{T} \quad$ tree

G grass

30 S plantgenus

The emission rate within the model from either tree canopy or grasses is a function of the fraction of the model grid cell occupied by tree canopy or grass (equation 2), the total leaf biomass (equation 3), and plant genus-specific emission rate (equations 13 and 14).

$35 \mathrm{Q}=\mathrm{f}\left(\mathrm{T}, \mathrm{PAR}, \mathrm{SZA}, \mathrm{LAI}, \mathrm{EF}_{\mathrm{s}}\right)$

Because the grass emis sions are $<1 \%$ of total, for the uncertainty analysis, grass emissions can be neglected. The SZA comes into the determination of fraction of shaded and sunlit leaves and is considered here to be a second order effect. The 
uncertainties are presented in Table 1. The uncertainty in LAI is determined by the maximum difference in slope between the LAIs from the comparis on of the MEGAN and the Lu et al. (2003) data set. The uncertainty in EFs in equation 18 is derived from the comparis on of the MEGAN and ABCGEM EFs at LAI interval $2-3$ in Figure 2 of the main paper. The uncertainty in the fractional coverage of a plant genus across thelandscape $\mathrm{F}_{\mathrm{T}}$ is based on a change of plant genus for $50 \%$ of the land area

5 from Eucalypts to either Acacia or Pittosporum (Emmers on et al. 2016). Such an uncertainty is based on the inadequate mapping of tree genera across the GMR area.

The following uncertainties are presented in Table 1: $\sigma_{E R}, \sigma_{L A I}, \sigma_{T}, \sigma_{P A R}, \sigma_{E F_{S}}, \sigma_{F_{T}}$

These are substituted in equation (6) to give the combined relative uncertainty.

$10 \sigma_{E R}^{2} / E R^{2}=\sigma_{L A I}^{2} / L A I^{2}+\sigma_{T}^{2} / T^{2}+\sigma_{P A R}^{2} / P A R^{2}+\sigma_{E F_{S}}^{2} / E F_{S}^{2}+\sigma_{F_{T}}^{2} / F_{T}^{2}$

The estimate is of the uncertainty in the isopreneemis sions averaged over the GMR domain for the period of a field campaign and as stated earlier represent $95 \%$ confidence limits. It is apparent from combining the relative variances from the uncertainties in Table 1, that the LAI, Emission Factor, EFs, and landscape coverage are the major sources of uncertainty in ABCGEM. The expanded combined relative uncertainty $0.82(95 \% \mathrm{CL})$. In fact because the relative uncertainty is approaching 1 , the uncertainties are probably asymmetric and expressing the result as a relative uncertainty of approximately a factor of 2 is probably more realistic. The result of the analysis indicates that plant genera BVOC emis sions, plant genera distribution and leaf area index are the key areas requiring more information to improve this ABCGEM modelling.

20 Table 1 Uncertainty analysis for campaign based ave rage emission

\begin{tabular}{|l|c|c|c|c|}
\hline Term & Variable & $\begin{array}{c}\text { Relative expanded } \\
\text { uncertainty }(\sigma)\end{array}$ & $\begin{array}{c}\text { Combined } \\
\text { expanded relative } \\
\text { uncertainty }\end{array}$ & Reference \\
\hline 1 Temperature & T (deg C) & 0.1 & & Cope et al. (2014) \\
\hline $\begin{array}{l}2 \text { Photosynthetic active } \\
\text { radiation }\end{array}$ & PAR & 0.1 & & This study \\
\hline $\begin{array}{l}\text { 3 Leaf area index } \\
\text { plant genus }\end{array}$ & LAI & 0.4 & & This study \\
\hline $\begin{array}{l}5 \text { Fractional cover of } \\
\text { plant genus }\end{array}$ & $\mathrm{FFs}$ & 0.5 & & This study \\
\hline
\end{tabular}




\section{Emission fluxes as a function of LAI}

Figure 3 pres ents the calculated average emissions (including AML) from the $3 \mathrm{~km}$ domains sorted by the LAI parameter. The MEGAN monoterpene emissions and volume mixing ratios used in the rest of this paper are the sum of 41 monotepene

5 species, and not just the 7 mapped species. Figure 3 shows each model's average emis sions with binned LAI, omitting emissions where the land area represents less than $1 \%$ of the model domain. The LAI is weighted by the fractional area taken up by each bin. The plots are arranged by time of year, with MUMBA first (January, Southern Hemisphere summer) to SPS2 (April). The standard deviation in emis sions are shown as error bars.

Figure 3 shows the MEGAN isoprene emissions have a greater relative variability than ABCGEM or AML. MEGAN has a 10 more enhanced curve to the is oprene emissions versus LAI, with a peak at $3-4 \mathrm{~m}^{2} \mathrm{~m}^{-2}$, decreasing with denser canopies for the reasons in the previous section. The ABCGEM is oprene emis sions increase with LAI, but are not linear, indicating the processing of the emission factors. In summer the isoprene emission estimates from MEGAN are distinctly higher than ABCGEM or AML, whereas there was some overlap in their emission factors. This demonstrates the impacts of the lower radiation activity function in ABCGEM across the main part of the day. Reduced temperatures and light levels in autumn cause

15 substantial overlap in the SPS2 is oprene emis sions for all models.

The AMLdomain average is oprene and monoterpene emis sions are $10 \%$ and $20 \%$ respectively different from ABCGEM and suggests that the choice (and age) of the LAIdataset is not critical to the BVOC emis sion estimates.

The ABCGEM and AML monoterpene emis sions are almost linear with LAI only overlapping with MEGAN below $2 \mathrm{~m}^{2} \mathrm{~m}^{-}$ ${ }^{2}$. When the LAI is more than $4 \mathrm{~m}^{2} \mathrm{~m}^{-2}$ the ABCGEM and AML monoterpene emis sions are 2 - 3 times greater than MEGAN 20 and the separation increases at high LAI. Whilst the monoterpene emission factors are similar between ABCGEM and MEGAN, and the influence of LAI is removed in AML, the lower MEGAN monoterpenes are impacted by the temperature activity function. To demonstrate the day/night differences, the SPS1 monoterpene emissions are split into daytime and nighttime hours (next section). By reducing the impact temperature has on monoterpene emissions, the MEGAN gradients in monoterpene emissions are approximately 3 times lower than ABCGEM and AMLduring the day and night.

25 Overall the isoprene and monoterpene emis sions show a greater divergence between ABCGEM and MEGAN than the emission factors. This arises because of differences in the emission activity algorithms and parameters within the two models. 

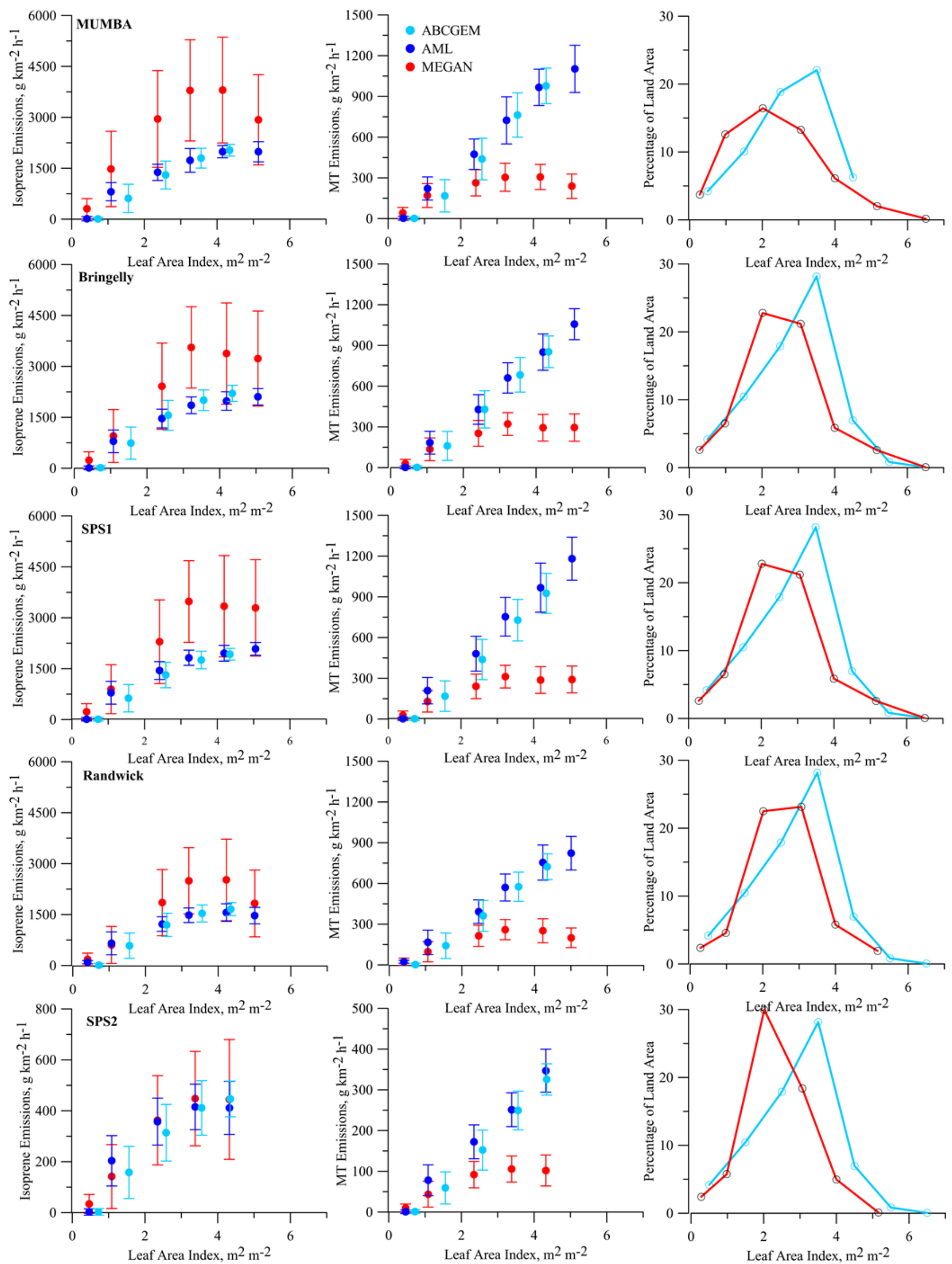

Figure 3 Distribution of gridcell average emissions with leaf area index for ABCGEM, AML and MEGAN (left) is oprene and (middle) monoterpenes (MT). Frror bars are \pm 1 standard deviation. (Right) Percentage of land area within each LAI bin for the ABCGEM and MEGAN MODIS LAI datasets. 


\subsection{Day and night time differences in emission fluxes}

As ABCGEM was developed 15 years ago independently of MEGAN, there are some subtle differences in the way the calculated emissions respond to temperature. ABCGEM uses $303 \mathrm{~K}$ as the standard temperature for both isoprene (equation 5) and monoterpene (equation 12) calculations. In MEGAN v2.1, a standard temperature of $297 \mathrm{~K}$ is used for light dependent 5 compounds, whilst $303.15 \mathrm{~K}$ is used for light independent compounds. There is also a differencein the value of $\beta$ in equation 12; ABCGEM uses 0.09, whereas MEGANuses 0.1.

The monoterpene emis sions from the SPS1 period are split into daytime (6:30 - 19:30 hours) and night time hours, and sorted by the LAI parameter in Figure 4. The daytime emis sions are approximately 2.5 times greater than thenight time emis sions in all models. However the gradient in ABCGEM/AML monoterpene emissions are approximately 3 times greater than the

10 MEGAN emissions. In MEGAN the impact of the temperature activity function is reduced because monoterpenes exhibit varying degrees of light dependency.
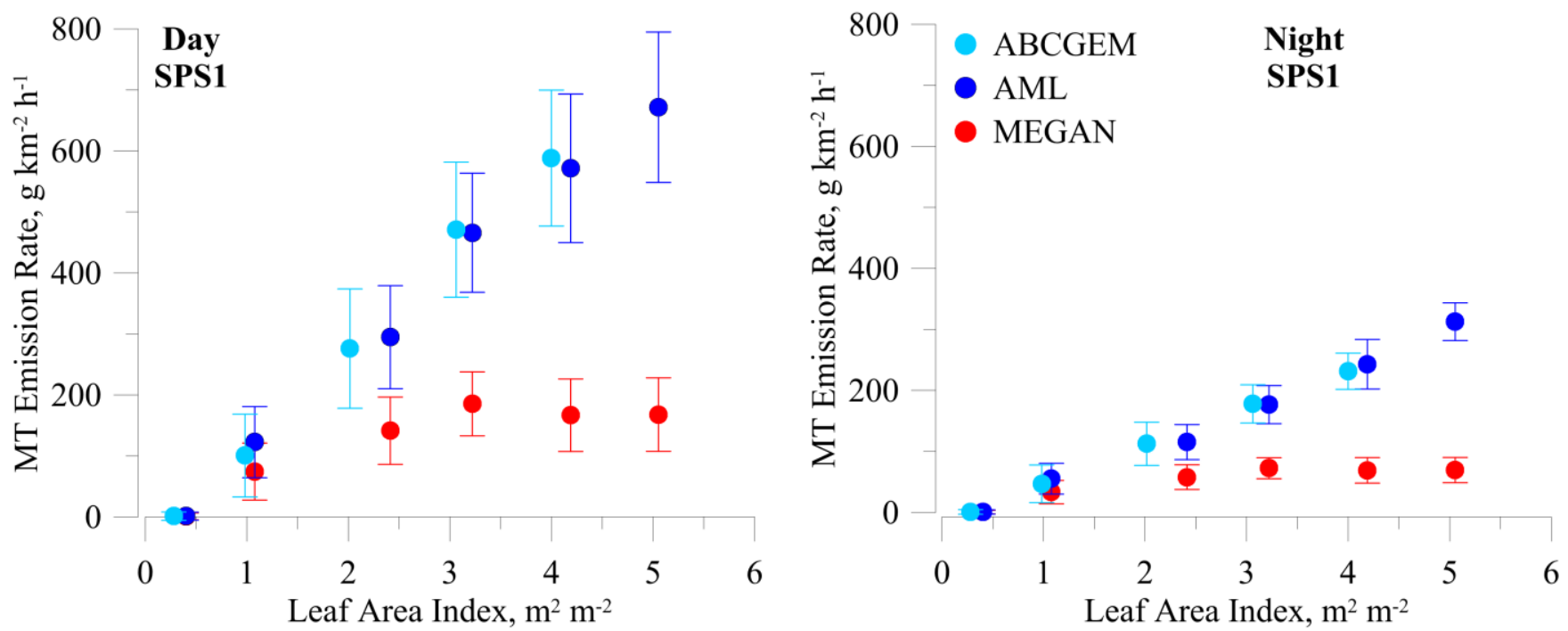

Figure 4 Impacts on average monoterpene (MT) emission fluxes in all models during SPS1 campaign split by (left) daytime and (right) night-time. 
SPS2 occurred during April/May of 2012, which is autumn in the southern hemis phere. Conditions were cooler than theother field campaigns studied, and the LAI dataset for the ABCGEM scheme at this time of year exhibited much more growth than the MEGAN LAI dataset. This led to higher isoprene predictions during SPS2 for ABCGEM compared with MEGAN, which

5 needed reasoning.

\subsection{Emission factors with LAI during SPS2}

Figure 5 shows how the is oprene and monoterpene emission factors between ABCGEM and MEGAN differ when compared with the respective scheme's LAI for the SPS2 period (tree LAI only for ABCGEM). The MEGAN is oprene emis sion factors plateau after the peak at LAI of $3-4 \mathrm{~m}^{2} \mathrm{~m}^{-2}$, whilst the ABCGEM isoprene emission factors keep increasing. The ABCGM

10 LAI has slightly more land grid cells at higher LAI values than the MEGAN LAI. The ABCGEM LAI peaks at $6.1 \mathrm{~m}^{2} \mathrm{~m}^{-2}$, whilst the MEGAN autumn LAI dataset here has a maximum of $5 \mathrm{~m}^{2} \mathrm{~m}^{-2}$. Note that these higher $5-6 \mathrm{~m}^{2} \mathrm{~m}^{-2}$ bin contain less than $1 \%$ of the land area and thus the emis sion factor points have been removed. $30 \%$ of the land area in MEGAN is in LAI bins $2-3 \mathrm{~m}^{2} \mathrm{~m}^{-2}$.

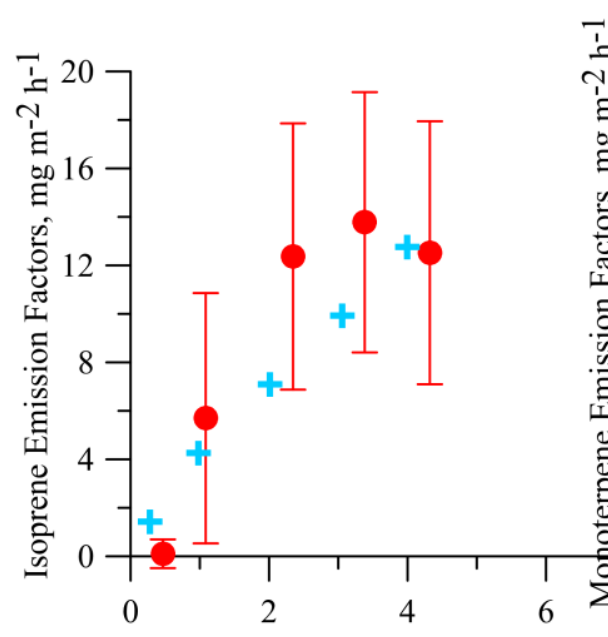

15

Figure 5 Scatter plot of the canopy isoprene (left) and monoterpene (middle) emission factors across the Sydney grid with LAI for ABCGEM and MEGAN during April/May. Note y-axes are not the same. (Right) percentage of land area taken up by each LAI bin in April/May (SPS2). Error bars represent \pm 1 standard deviation.

\section{$20 \quad 5.2$ Spatial distributions of emission fluxes during SPS2}

Figure 6 shows maps of the grid cell average emis sions for MEGAN and ABCGEM for the timing of the SPS2 field campaign, followed by the differences in between MEGAN and ABCGEM. Compared with the summer period of SPS1, the autumal SPS2 is opreneemis sions are a factor of $\sim 8$ lower in MEGAN compared with SPS1 and a factor of $\sim 3$ lower for monotemenes in ABCGEM. The emissions for SPS2 show similar patterns as were seen in the SPS1 distributions. These relate to thehigher ABCGEM isoprene emission within the Sydney urban and suburban areas than MEGAN, and the higher MEGAN monoterpenes to the immediate south west of Sydney. 

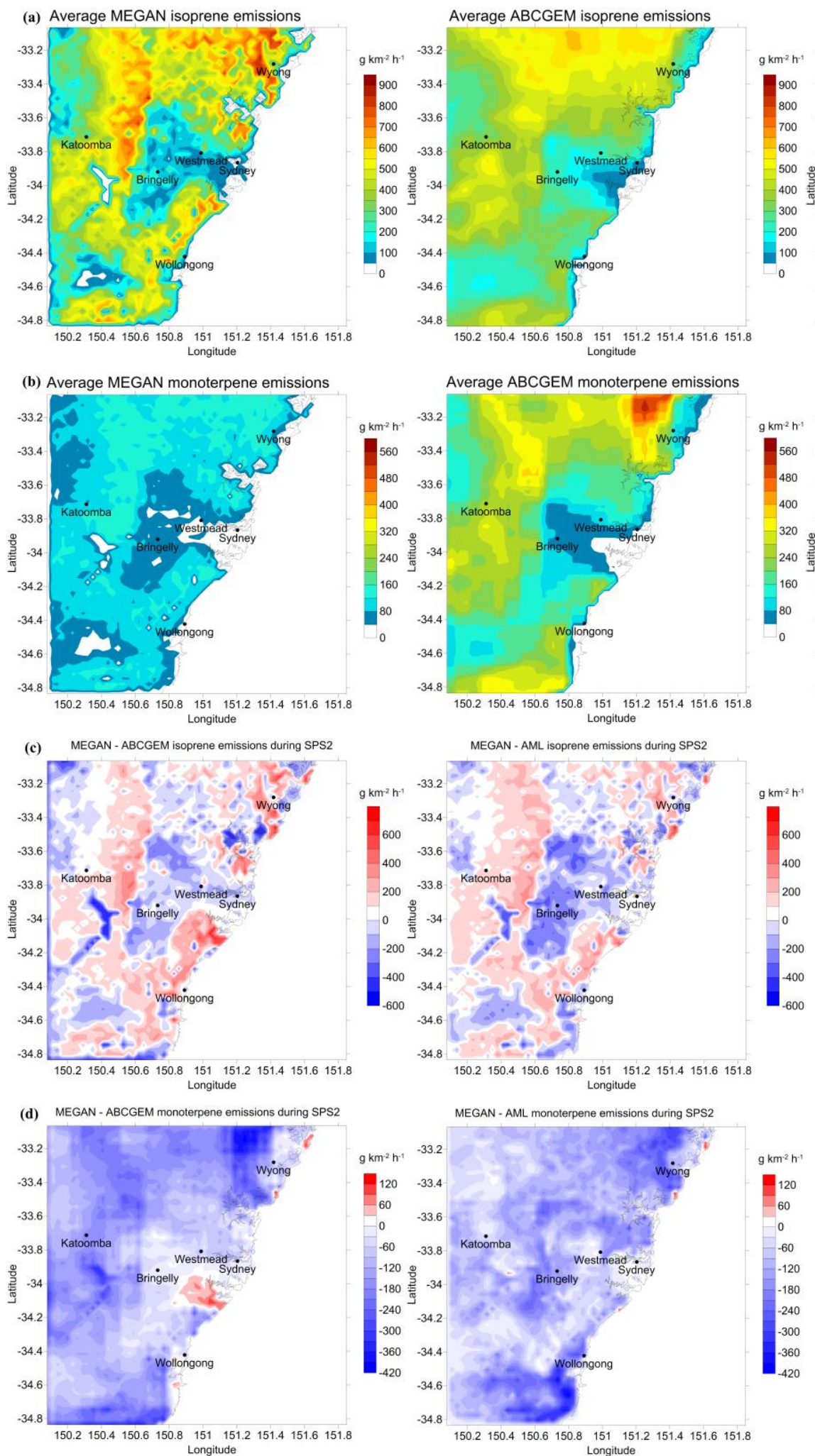

Figure 6 Spatial distributions of grid cell average emission fluxes for (a) is oprene (b) monoterpenes, and the differences between MEGAN with ABCGEM or AML emissions for (c) isoprene and (d) monoterpenes for the SPS2 campaign. Note: scales are unalike for is oprene and monoterpenes. 


\section{Wind rose analyses}

Measurements of wind speed and direction were taken at the field campaign sites, and provide information on the meteorological conditions experienced (Figure 7). Wollongong and Randwick sites are both close to the coast and yet exhibit different diurnal cycles in isoprene (both measured and modelled). The Wollongong isoprene diurnal profile is as expected,

5 with high is oprene at noon. The Rand wick isoprene diurnal profile is not expected, with an is oprene peak before 9am, which then tails away to low volume mixing ratios during the daylight hours. Campaign average wind roses are plotted of the observations in Figure 7, and show where the influences of each field site are coming from, e.g. Bringelly fromthe south west, and SPS1 from the north west; both regions of high is oprene emis sion factors. However these wind roses do not show the average diurnal variation required for Wollongong and Randwick, as it is suspected that fresh onshore air masses must be

10 reaching Randwick during daylight hours.
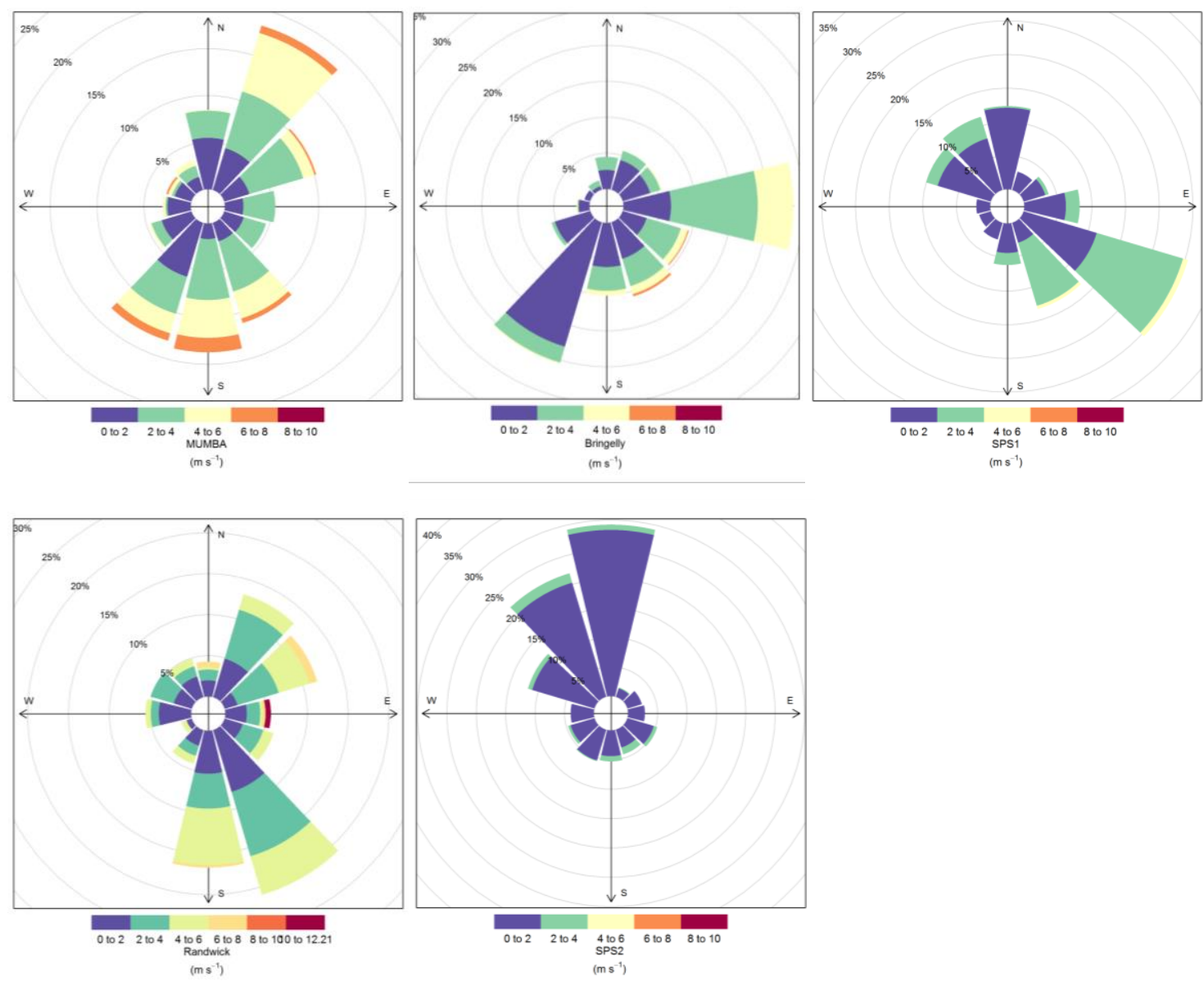

Figure $7 \mathrm{O}$ bserved wind roses for each field campaign.

15 The position of Wollong ong and Rand wick are shown in Figure 8 with the campaign average wind rose aligned due north. This demonstrates that the MUMBA site at Wollongong will still receive the bulk of its air mases after transport over land. The Randwick site has some stronger easterlies which will be fresh sea air. The timings of the wind mass changes are better observed by splitting the datainto hourly wind roses. 


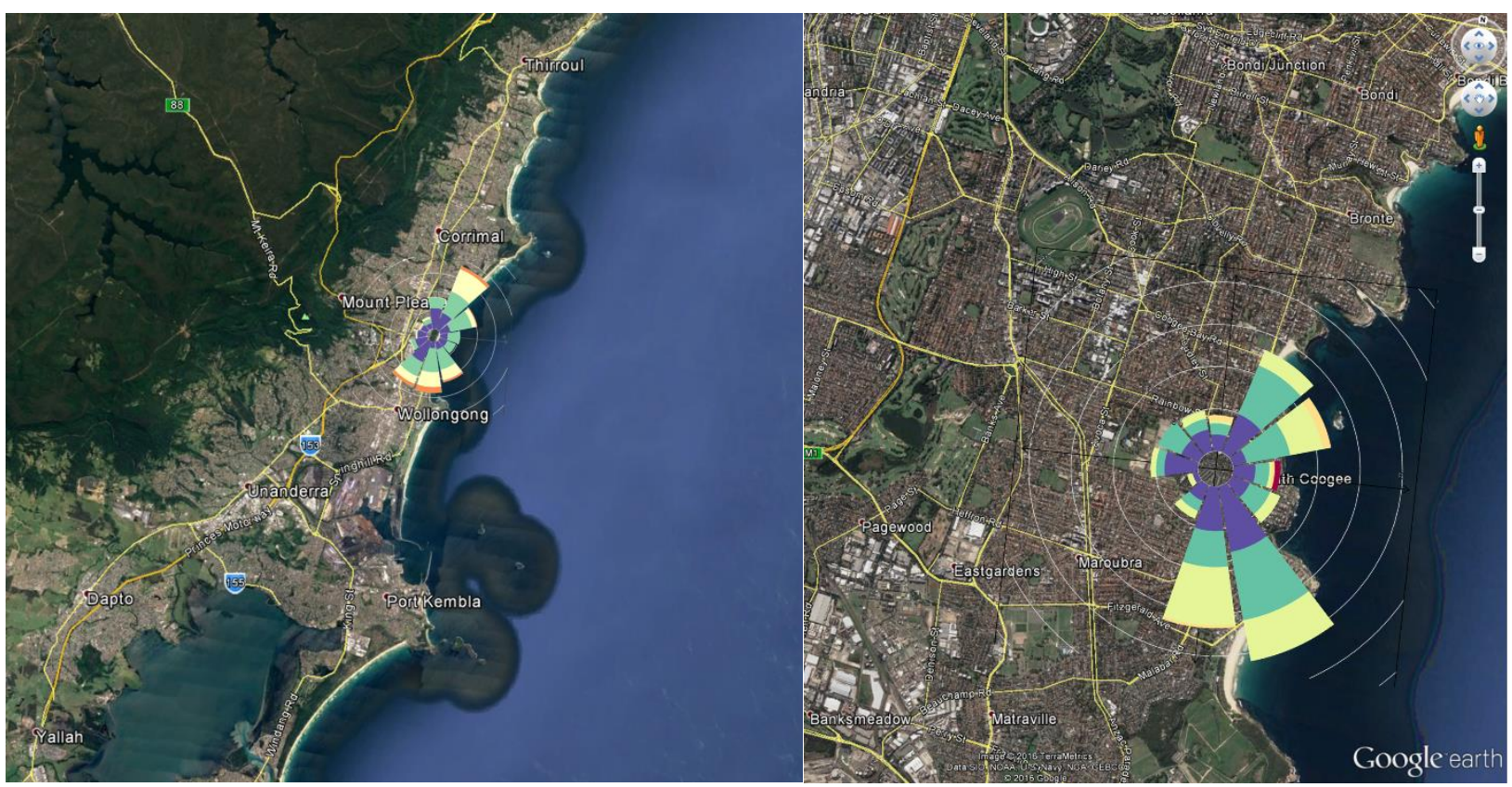

Figure 8 Maps to demonstrate average wind direction at MUBA (left) and Randwick (right) field sites.

The MUMBA wind roses (Figure 9) show winds blowing from the south west until 8am when they start to swing from the south east until noon and then from the north east in the early afternoon until $7 \mathrm{pm}$. Winds then become lighter in strength.

5 The Randwick wind roses (Figure 10) show a different pattern. There are gaps in the meas urements, however before 9amthere are generally light winds. The wind speed picks up after 11amblowing from the south east and easterly directions, with speeds of up to $12 \mathrm{~m} \mathrm{~s}^{-1}$ from the eas t between 2 and $4 \mathrm{pm}$. After 5pm, there are stronger winds from the north east. The position of Randwick near the coast suggests that there would be few biogenic air mass es reaching the site after 11am. The meteorology explains the difference in diurnal is oprene levels observed at Wollongong and Randwick. The monoterpene diurnal profiles are not affected as fast reaction times during the day mean their levels only build up overnight when wind speeds are calmer. 


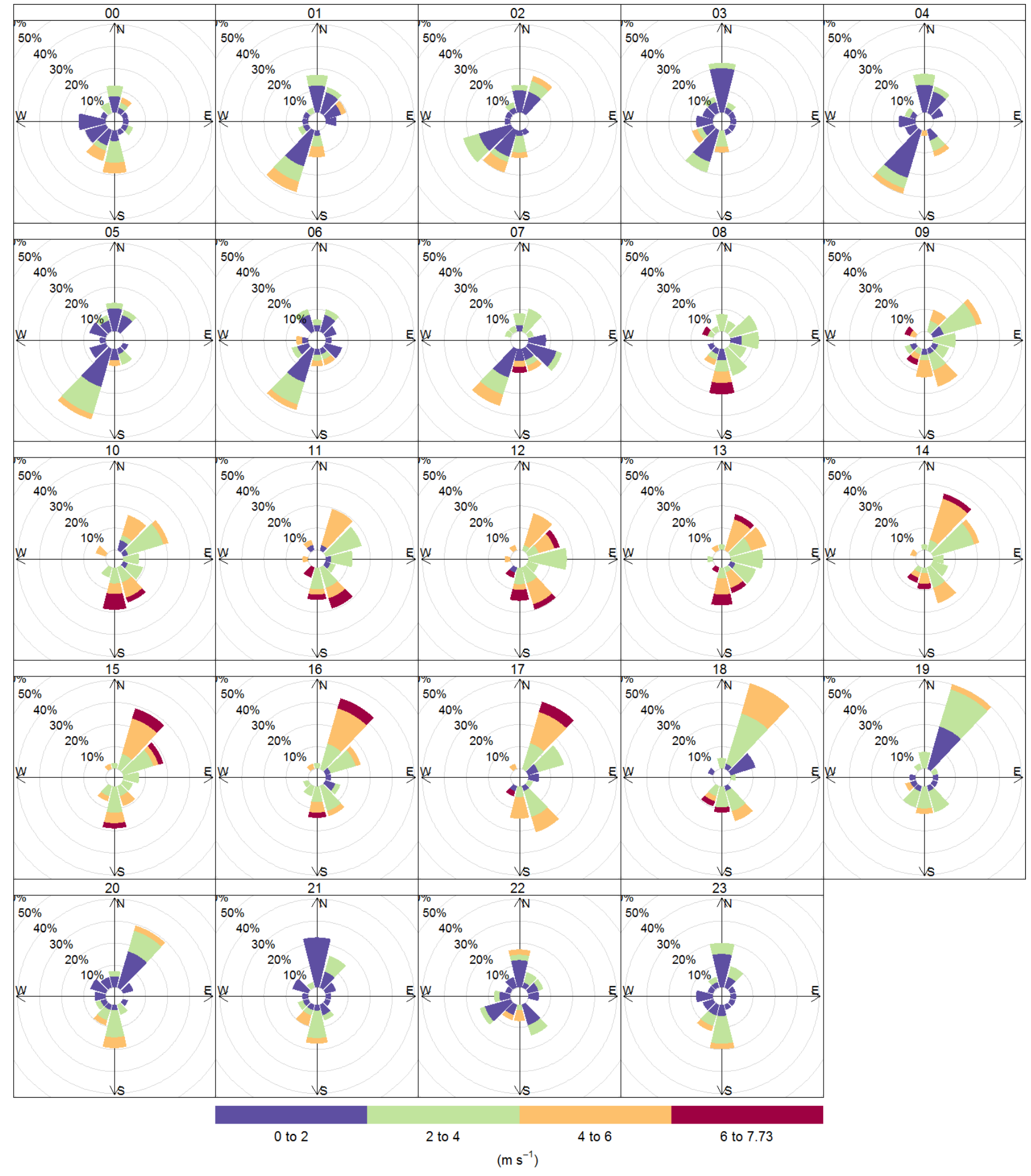

Figure 9. Wind roses, plotted each hour, ave raged for the MUMB A observations. 


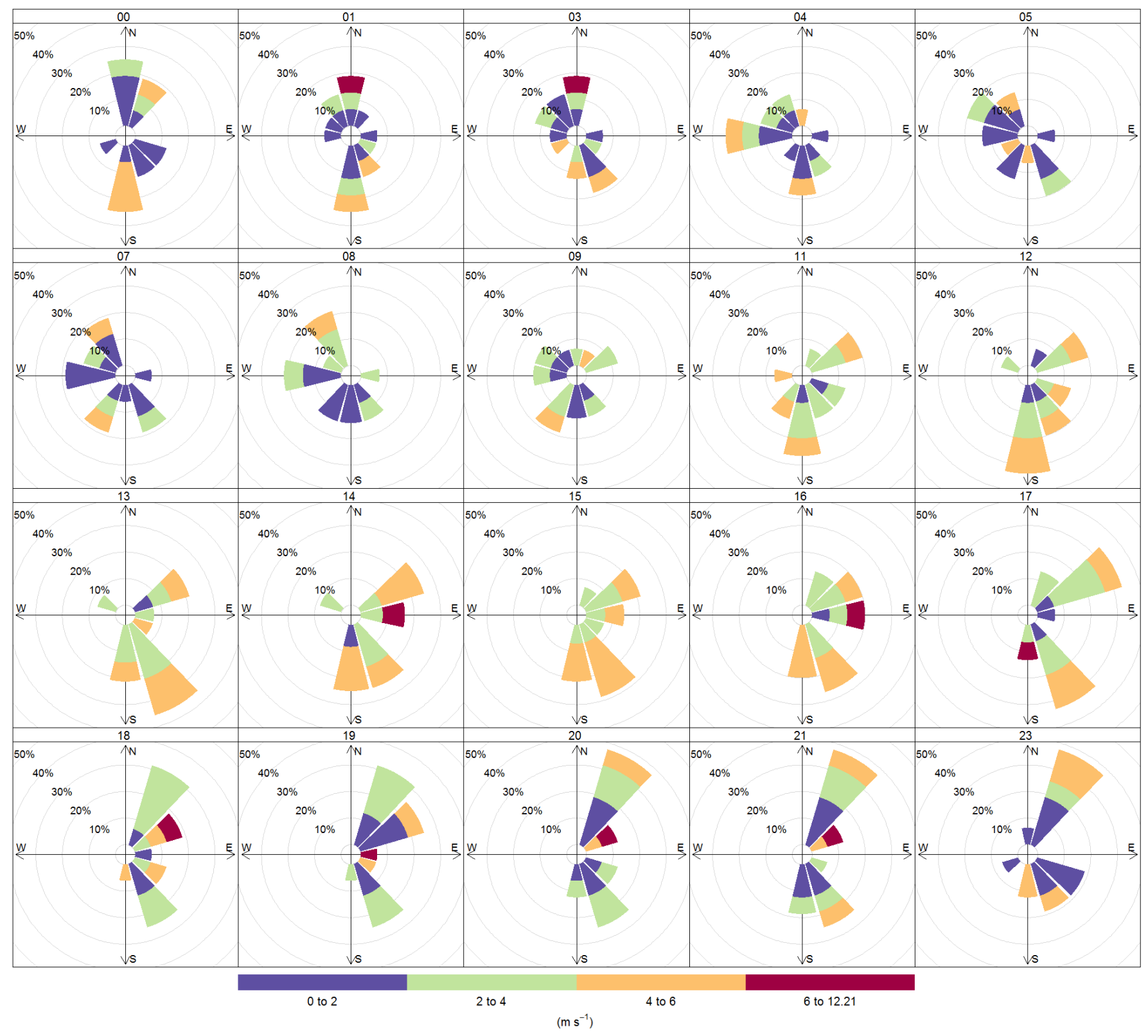

Figure 10 Wind roses, plotted each hour, averaged for the Randwick observations. Note, there are gaps in the observations at 2 am, 6am, 10am and $10 \mathrm{pm}$.

\subsection{Bringelly}

5 The observed isoprene and monoterpene volume mixing ratios at Bringelly are lower than for other sites, despite the close (16km) proximity of the Blue Mountain region to the west. Additional wind roses are plotted for this field campaign, splitting the time period into daytime and night time (Figure 11). We also include wind roses for the modelled data, and also two polar bivariate plots for observed and modelled monoterpenes. During daytime, the observed and modelled wind direction is from the east, directly from the urb an Sydney region. At night, when monoterpene levels are highest, the observed wind direction

10 is from the south-south west, mostly at low wind speeds less than $2 \mathrm{~ms}^{-1}$. In the model, the direction of the peak monotemenes has more of a south-westerly to westerly influence than the observations, at higher wind speeds up to $8 \mathrm{~m} \mathrm{~s}^{-1}$. We think the higher modelled wind speeds, and more westerly influence of the wind direction at night has contributed to the higher monoterpenes in the model. During the daytime when is oprene is more prevalent, the observed wind direction is away from the forests, keeping the observed is oprene low. In the model, there is a south westerly influence in the day time with high wind

15 speeds up to $10 \mathrm{~m} \mathrm{~s}^{-1}$, meaning the modelled is oprene is higher than observed. 

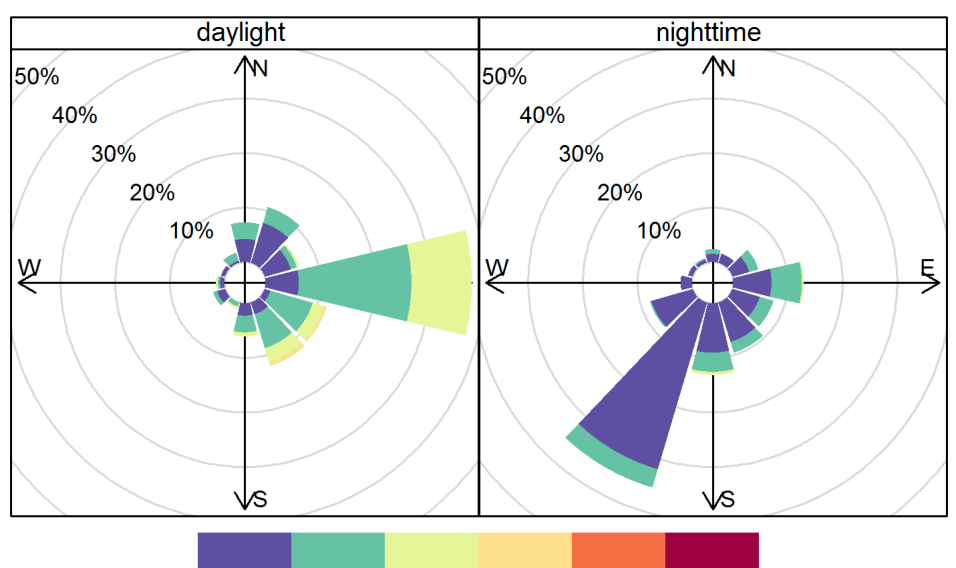

0 to 22 to $4 \quad 4$ to $6 \quad 6$ to 88 to 1010 to 12

Bringelly observations, $\mathrm{m} \mathrm{s}^{-1}$

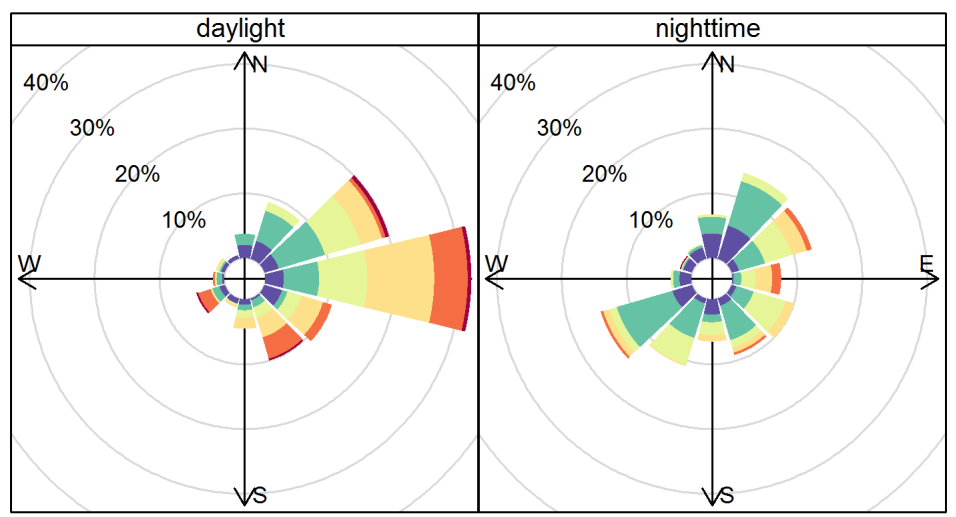

0 to 22 to $4 \quad 4$ to $6 \quad 6$ to 88 to 1010 to 12 Bringelly model, $\mathrm{m} \mathrm{s}^{-1}$
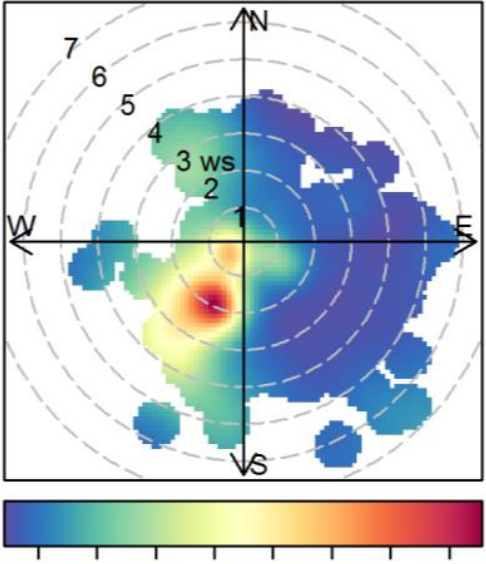

$0.20 .40 .6 \quad 0.8 \quad 1 \quad 1.21 .41 .6$ Bringelly monoterpenes, $\mathrm{ppb}$

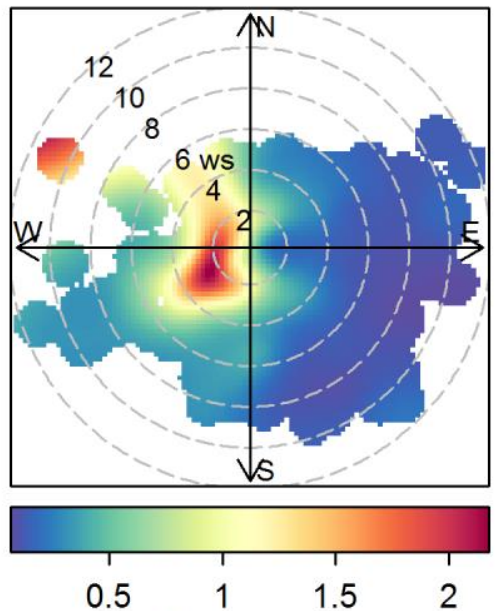

Bringelly (ABCGEM) monoterpenes, ppb

Figure 11 (left) wind roses split by daylight and night time hours and (right) polar bivariate plots for monoterpenes from the (top) observations and (bottom) model. 
Berrington, P. R., and Robins on, D. K.: Data reduction and error propagation for the physical sciences, McGraw-Hill, Boston, 328 pp., 1992.

Emmerson, K. M., Galbally, I. E., Guenther, A. B., Paton-Walsh, C., Guerette, E. A., Cope, M.E., Keywood, M.D.,

5 Lawson, S. J., Molloy, S. B., Dunne, E., Thatcher, M., Karl, T., and Maleknia, S. D.: Current es timates of biogenic emissions from eucaly pts uncertain for southeast Australia, Atmos ChemPhys, 16, 6997-7011, 10.5194/acp-16-6997-2016, 2016. Guenther, A. B., Monson, R. K., and Fall, R.: Is oprene and Monoterpene Emis sion Rate Variability - Observations with Eucalyptus and Emis sion Rate AlgorithmDevelopment, J Geophys Res -Atmos, 96, 10799-10808, Doi 10.1029/91jd00960, 1991.

10 Guenther, A. B., Zimmerman, P. R., Harley, P. C., Monson, R. K., and Fall, R.: Isopreneand Monoterpene Emis sion Rate Variability - ModelEvaluations and Sensitivity Analyses, J Geophys Res -Atmos, 98, 12609-12617, Doi 10.1029/93jd00527, 1993.

Harley, P., Guenther, A., and Zimmerman, P.: Environmental controls over isoprene emiss ion in deciduous oak canopies, Tree Physiol, 17, 705-714, 1997.

15 Harris, D. C.: Quantitative Chemical Analysis, 6th Edition ed., W.H. Freeman and Co, New York, 2003. JCGM: JCGM 100: 2008 Evaluation of measurement data. Guide to the expres sion of uncertainty in measurement. , BIPM, Sevres, France, 2008.

Kattge, J., Diaz, S., Lavorel, S., Prentice, C., Leadley,P., Bonisch, G., Garnier, E., Westoby, M., Reich, P. B., Wright, I. J., Cornelis sen, J.H. C., Violle, C., Harris on, S. P., van Bodegom, P. M., Reichstein, M., Enquist, B. J., Soudzilovskaia, N. A.,

20 Ackerly, D. D., Anand, M., Atkin, O., Bahn, M., Baker, T. R., Baldocchi, D., Bekker, R., Blanco, C. C., Blonder, B., Bond, W. J., Bradstock, R., Bunker, D. E., Cas anoves, F., Cavender-Bares, J., Chambers, J. Q., Chapin, F. S., Chave, J., Coomes, D., Cornwell, W. K., Craine, J. M., Dobrin, B. H., Duarte, L., Durka, W., Elser, J., Es ser, G., Estiarte, M., Fagan, W. F., Fang, J., Fernandez-Mendez, F., Fidelis, A., Finegan, B., Flores, O., Ford, H., Frank, D., Fres chet, G. T., Fyllas, N. M., Gallagher, R. V., Green, W. A., Gutierrez, A. G., Hickler, T., Higgins, S. I., Hodgs on, J. G., Jalili, A., Jans en, S., Joly, C. A., 25 Kerkhoff, A. J., Kirkup, D., Kitajima, K., Kleyer, M., Klotz, S., Knops, J. M. H., Kramer, K., Kuhn, I., Kurokawa, H., Laughlin, D., Lee, T. D., Leishman, M., Lens, F., Lenz, T., Lewis, S. L., Lloyd, J., Llusia, J., Louault, F., Ma, S., Mahecha, M. D., Manning, P., Massad, T., Medlyn, B. E., Messier, J., Moles, A. T., Muller, S. C., Nadrowski, K., Naeem, S., Niinemets, U., Nollert, S., Nuske, A., Ogaya, R., Oleksyn, J., Onipchenko, V. G., Onoda, Y., Ordonez, J., Overbeck, G., Ozinga, W. A., Patino, S., Paula, S., Pausas, J. G., Penuelas, J., Phillips, O. L., Pillar, V., Poorter, H., Poorter, L., Poschlod,

30 P., Prinzing, A., Proulx, R., Rammig, A., Reinsch, S., Reu, B., Sack, L., Salgado-Negre, B., Sardans, J., Shiodera, S., Shipley, B., Siefert, A., Sosinski, E., Sous sana, J. F., Swaine, E., Swenson, N., Thompson, K., Thornton, P., W aldram, M., Weiher, E., White, M., White, S., Wright, S. J., Yguel, B., Zaehle, S., Zanne, A. E., and Wirth, C.: TRY - a globaldatabase of plant traits, GlobalChangeBiol, 17, 2905-2935, 10.1111/j.1365-2486.2011.02451.x, 2011.

Lamb, B., Gay, D., Wes tberg, H., and Pierce, T.: A Biogenic Hydrocarbon Emis sion Inventory for the USA Using a Simple

35 Forest Canopy Model, Atmos Environ a-Gen, 27, 1673-1690, Doi 10.1016/0960-1686(93)90230-V, 1993.

Norman, J. M. I. J. E.: Simulation of microclimates, in: Biometeorology in Integrated Pest Management., edited by: Hatfield, J. L., and Thomas on, I., Academic Pres s, New York,, 65-99., 1982.

Sharkey, T. D., Singsaas, E. L., Vanderveer, P. J., and Geron, C.: Field measurements of isoprene emis sion from trees in response to temperature and light, Tree Physiol, 16, 649-654, 1996.

40 Simon, V., Clement, B., Riba, M. L., and Torres, L.: The Landes Experiment - Monoterpenes Emitted from the Maritime Pine, J Geophys Res-Atmos, 99, 16501-16510, Doi 10.1029/94jd00785, 1994.

Tingey, D. T., Manning, M., Grothaus, L. C., and Burns, W. F.: Influence of Light and Temperature on Monoterpene Emis sion Rates fromSlash Pine, Plant Physiol, 65, 797-801, DOI 10.1104/pp.65.5.797, 1980.

Wright, I. J., Westoby, M., and Reich, P. B.: Convergence towards higher leaf mas s per area in dry and nutrient-poor habitats has different consequences for leaf life span, J Ecol, 90, 534-543, DOI 10.1046/j.1365-2745.2002.00689.x, 2002.

Zhang, L. M., Moran, M. D., and Brook, J. R.: A comparis on of models to estimate in-canopy photosynthetically active radiation and their influence on canopy s tomatal res is tance, Atmos Environ, 35, 4463-4470, Doi 10.1016/S13522310(01)00225-4, 2001. 